\title{
Effects of combination therapy with mitiglinide and voglibose on postprandial plasma glucose in patients with type 2 diabetes mellitus
}

This article was published in the following Dove Press journal: Diabetes, Metabolic Syndrome and Obesity:Targets and Therapy 30 August 2013

Number of times this article has been viewed

\author{
Hiroyuki Konya' \\ Tomoyuki Katsuno ${ }^{2}$ \\ Taku Tsunoda' \\ Yuzo Yano' \\ Mai Kamitani' \\ Masayuki Miuchi² \\ Tomoya Hamaguchi ${ }^{3}$ \\ Jun-Ichiro Miyagawa ${ }^{2}$ \\ Mitsuyoshi Namba ${ }^{2}$ \\ 'Department of Internal Medicine, \\ Ashiya Municipal Hospital, Ashiya, \\ Hyogo, Japan; 'Division of Diabetes, \\ Endocrinology and Metabolism, \\ Department of Internal Medicine, \\ Hyogo College of Medicine, \\ Nishinomiya, Hyogo, Japan; ${ }^{3}$ Division \\ of Innovative Diabetes Treatment, \\ Hyogo College of Medicine, \\ Nishinomiya, Hyogo, Japan
}

Correspondence: Hiroyuki Konya Department of Internal Medicine, Ashiya Municipal Hospital, 39-I, Asahigaoka-cho, Ashiya, Hyogo 659-8502, Japan

Tel $+8 \mid 7973$ I 2 I56

$\mathrm{Fax}+81797228822$

Email h-dyer@mvi.biglobe.ne.jp

\begin{abstract}
Patients with diabetes mellitus are at increased risk from cardiovascular-related morbidity and mortality as compared with healthy individuals. An association between the postprandial metabolic state and atherogenesis has been observed in patients with diabetes mellitus. In the Study to Prevent Non-Insulin-Dependent Diabetes Mellitus (STOP-NIDDM), treatment with an $\alpha$-glucosidase inhibitor $(\alpha-\mathrm{GI})$ in patients with impaired glucose tolerance not only reduced the rate of conversion from impaired glucose tolerance to type 2 diabetes mellitus (T2DM), but was also associated with a reduction in the risk of cardiovascular events. These results suggested the importance of treating postprandial hyperglycemia in the early stages of T2DM. Glinides are rapid and short-acting insulin secretagogues that bind to the sulfonylurea receptors on pancreatic $\beta$-cells to facilitate rapid insulin secretion, restore postprandial early insulin secretion, and reduce the postprandial glucose spike. Moreover, $\alpha$-GIs reduce postprandial hyperglycemia and insulin secretion by delaying the digestion of carbohydrates and polysaccharides in the small intestine. Then, both glinides and $\alpha$-GI have beneficial effects for treating patients with T2DM and impaired glucose tolerance. Considering the ameliorating effects of these drugs on postprandial metabolic disorders, combinations of glinides and $\alpha$-GI might constitute a promising therapeutic strategy for managing patients with T2DM, and also appear to be suitable for Japanese people, who consume more carbohydrates, such as polished rice, than Caucasians. It has recently been reported that combined use of mitiglinide and voglibose reduces postprandial insulin secretion and blunts diurnal glycemic changes in T2DM patients. This therapy can thus be regarded as being suitable for achieving strict postprandial glycemic control. In this report, we outline the effects of this combination therapy on postprandial plasma glucose and assess its safety.
\end{abstract}

Keywords: mitiglinide, voglibose, combination therapy, type 2 diabetes mellitus, postprandial hyperglycemia

\section{Introduction}

Patients with diabetes mellitus (DM) are at increased risk for cardiovascular diseaserelated morbidity and mortality as compared with healthy individuals. ${ }^{1}$ A relationship between the postprandial metabolic state and atherogenesis has been demonstrated, ${ }^{2,3}$ and has also been documented in DM patients. ${ }^{4,5}$ It has been suggested that postprandial hyperglycemia may be an independent risk factor for cardiovascular disease. ${ }^{6}$ Moreover, large-scale clinical trials, such as the Diabetes Epidemiology: Collaborative analysis Of Diagnostic criteria in Europe (DECODE) study, have shown that postprandial hyperglycemia is a risk factor for arteriosclerosis, independent of other established risk factors such as hypertension and hyperlipidemia. ${ }^{7,8}$ In the Study to 
Prevent Non-Insulin-Dependent Diabetes Mellitus (STOPNIDDM), treatment with an $\alpha$-glucosidase inhibitor ( $\alpha$-GI) in patients with impaired glucose tolerance (IGT) not only reduced the rate of conversion to type 2 DM (T2DM), but was also associated with a reduction in the risk of cardiovascular events. ${ }^{9}$ These results suggested the importance of treating postprandial hyperglycemia in the early stages of DM. Although sulphonylureas (SU) have been widely used for the treatment of DM, they do not act rapidly enough to increase glucose-stimulated insulin secretion after a meal and are, therefore, insufficient to control postprandial hyperglycemia. Since it has been shown that SU can easily cause prolonged hypoglycemia and weight gain, they have to be used with caution in the early stages of T2DM. ${ }^{10,11}$

Although glinides are insulin secretagogues that bind to the SU receptors of pancreatic $\beta$-cells as well, they can facilitate rapid insulin secretion, restore postprandial early insulin secretion, and reduce the postprandial glucose spike. On the other hand, $\alpha$-GI reduces postprandial hyperglycemia and insulin secretion by delaying the digestion of carbohydrates in the small intestine. Both glinides and $\alpha$-GI have beneficial effects for treating patients with T2DM and IGT.
Considering the ameliorating effects of these drugs on postprandial metabolic disorders, combinations of glinides and $\alpha$-GI might constitute a promising therapeutic approach for patients with T2DM. Although voglibose exerts a slightly less potent effect in reducing postprandial hyperglycemia than acarbose and miglitol, it has the advantage of fewer gastrointestinal adverse events. ${ }^{12}$ Therefore, voglibose is widely used in Japan to reduce postprandial hyperglycemia in both T2DM and IGT patients. ${ }^{13}$ Mitiglinide calcium hydrate (mitiglinide) is a glinide that was developed in Japan and is occasionally used as monotherapy or in combination with other oral hypoglycemic agents for the treatment of T2DM in Japan (Figure 1). ${ }^{14-17}$

Several clinical investigations have also confirmed the beneficial effects of combining glinides with $\alpha$-GIs. ${ }^{18-20}$ A fixed-dose combination tablet consisting of $10 \mathrm{mg}$ of mitiglinide and $0.2 \mathrm{mg}$ of voglibose was recently approved in Japan. ${ }^{21}$ A small number of interesting reports on these drugs has recently been published, but the data were obtained from relatively small subject groups. Thus, this review aims to summarize the effects of combined therapy with mitiglinide and voglibose.

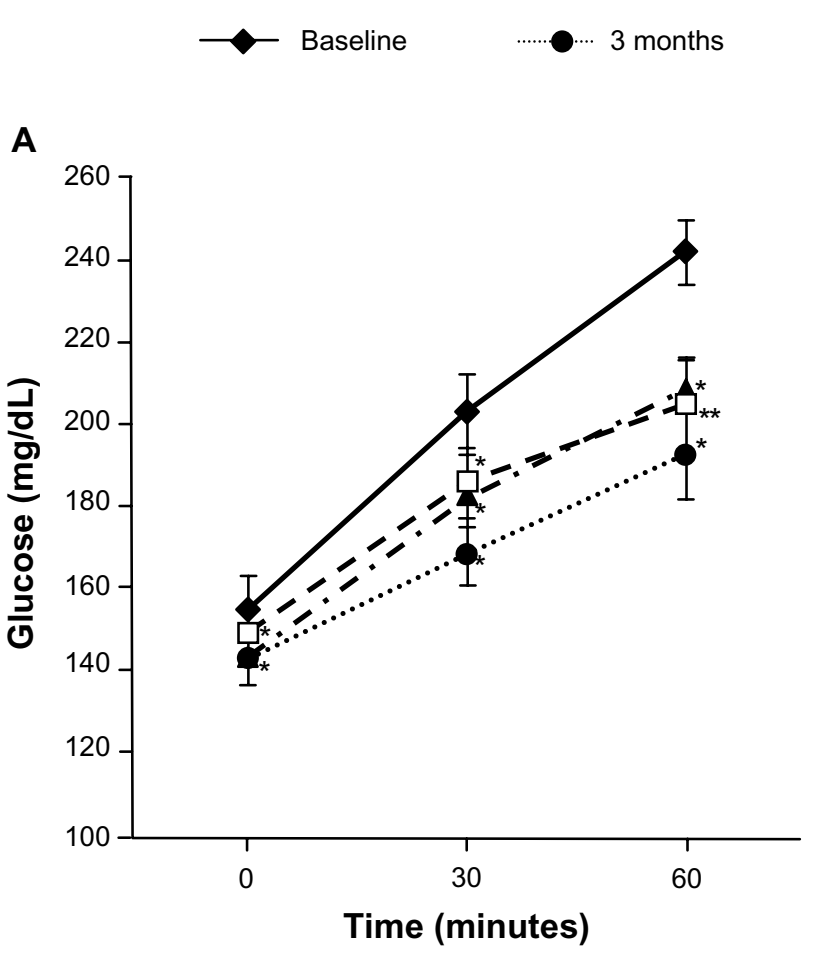

-. -6 months

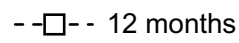

B

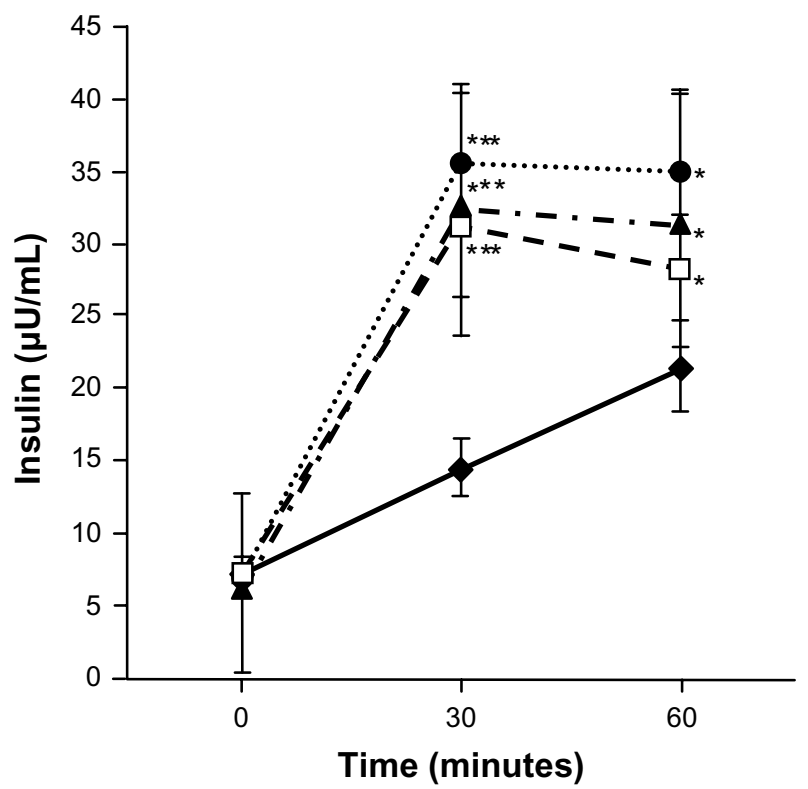

Figure I Postprandial plasma glucose levels and postprandial immunoreactive insulin levels with patients with type 2 diabetes mellitus treated with mitiglinide for 12 months.

Notes: (A) Postprandial plasma glucose levels and (B) postprandial immunoreactive insulin levels in patients with type 2 diabetes mellitus treated with mitiglinide for 12 months. Wilcoxon signed rank test was used to compare the differences between baseline values and those at 3 months, 6 months, and I 2 months posttreatment ( $\mathrm{n}=\mathrm{I} 6$ ). $* P<0.05 ; * * P<0.005$; ***P $<0.00$ I versus baseline (mean \pm SE). Copyright $@ 2009$, SAGE Publications. Adapted with permission from Konya H, Miuchi M, Konishi K, et al. Pleiotropic effects of mitiglinide in type 2 diabetes mellitus. J Int Med Res. 2009;37(6):1904-1912.16

Abbreviations: $n$, number; SE, standard error of the mean. 


\section{Pharmacology, mode of action, and pharmacokinetics of mitiglinide monotherapy}

Mitiglinide, a derivative of benzylsuccinic acid, closes adenosine triphosphate-dependent $\mathrm{K}^{+}$channels by selectively binding to the SU receptor on pancreatic $\beta$-cells, which leads to opening of the voltage-dependent calcium channels and induces insulin secretion. ${ }^{22}$ Mitiglinide has stronger affinity for SU receptors (SUR)1 than other insulinotropic SU receptor ligands, namely, repaglinide and nateglinide. ${ }^{23}$ In addition to its glucose-lowering effect, mitiglinide inhibits postprandial hypertriglyceridemia in Otsuka Long-Evans Tokushima Fatty rats, which exhibit insulin resistance and visceral fat accumulation, and are regarded as models of diabetes development with aging. ${ }^{24}$ Mitiglinide also improves postprandial hyperglycemia in T2DM patients via both an insulin-mediated indirect effect on the liver and a direct regulatory influence on hepatic glucose metabolism. ${ }^{25}$

Among the pharmacokinetic parameters of mitiglinide administered to healthy adult male subjects in a single dose of $5 \mathrm{mg}, 10 \mathrm{mg}$, or $20 \mathrm{mg}$ immediately before a meal, the time to peak plasma concentration $\left(\mathrm{C}_{\max }\right)$ after administration was $0.23-0.28$ hours and the half-life $\left(\mathrm{t}_{1 / 2}\right)$ was about 1.2 hours. ${ }^{26}$ On the other hand, for nateglinide, which was similarly administered in a single dose of $20 \mathrm{mg}, 40 \mathrm{mg}$, or $60 \mathrm{mg}$, the corresponding values were $0.9-1.8$ hours $\left(\mathrm{C}_{\max }\right)$ and 1.1-1.3 hours $\left(\mathrm{t}_{1 / 2}\right) \cdot{ }^{27}$ Similarly, repaglinide administered in a single dose of $0.25 \mathrm{mg}, 0.5 \mathrm{mg}$, or $1.0 \mathrm{mg}$ reached the $\mathrm{C}_{\max } 0.5$ hours later with $\mathrm{at}_{1 / 2}$ of about 0.8 hours. ${ }^{28}$ These data indicate that, whereas an initial rise in blood concentration is more rapid for mitiglinide than for nateglinide and repaglinide, the half-life of mitiglinide is almost the same as those of the other two glinides.

The pharmacokinetic properties of mitiglinide include rapid absorption and elimination. Thus, mitiglinide triggers a rapid and short-acting insulin secretory response that improves postprandial hyperglycemia, mimicking normal physiological insulin secretion and glucose metabolism in healthy individuals. Its preprandial administration controls postprandial hyperglycemia and improves overall glycemic control. ${ }^{29}$ Because it is a short-acting agent, mitiglinide is unlikely to exert adverse hypoglycemic effects early in the morning or between meals. ${ }^{30}$ Therefore, mitiglinide may become a first choice drug for managing the early stage of T2DM.

Moreover, suppression of postprandial hyperglycemia with mitiglinide has been reported to prevent postprandial increases in oxidative stress and markers of inflammation in DM patients. ${ }^{31}$ If mitiglinide even partially regulates oxidative stress and vascular inflammation, it could be used to prevent the cardiovascular complications of DM. Mitiglinide treatment significantly reduced plasma nitrotyrosine, malondialdehyde, and oxidized low density lipoprotein levels. Additionally, mitiglinide administration preserved the plasma total radical-trapping antioxidant parameter as compared with a placebo. Importantly, mitiglinide decreased the levels of proinflammatory cytokines such as interleukin-6, interleukin-18, and tumor necrosis factor- $\alpha$. However, the study demonstrating these reductions examined only the effect of acute administration of mitiglinide; it appears that reducing postprandial oxidative stress and inflammation may result in long-term cardiovascular preventive effects in diabetic patients.

Though the use of SU agents in T2DM patients remains quite common, increased risk of cardiovascular complications and increased fatality rates after myocardial infarction have been reported in such patients. ${ }^{32}$ SUR, which constitute the adenosine triphosphate-sensitive $\mathrm{K}^{+}$channel, have three subtypes with differing distributions: SUR1 (present in pancreatic $\beta$-cells), SUR2A (cardiac myocytes), and SUR2B (vascular smooth muscle cells). ${ }^{33,34}$ Accordingly, in vitro selectivity for insulin secretagogues may have an important impact on cardiovascular outcomes of diabetic patients with coronary artery disease. ${ }^{33}$ In isolated perfused rat hearts, mitiglinide (a selective blocker for SUR1) preserved the cardioprotective effect of ischemic preconditioning as compared to glibenclamide (a nonselective SUR blocker). ${ }^{35}$ In another study on isolated perfused rat hearts, glibenclamide induced a significant increase in left ventricular end-diastolic pressure and significantly decreased left ventricular systolic/developed pressure, while glimepiride only significantly decreased left ventricular developed pressure. ${ }^{36}$ However, mitiglinide had no effects on canine isolated coronary arteries or perfused rat hearts. Therefore, mitiglinide may have more certain benefits in terms of its cardiovascular effects than glibenclamide and glimepiride in DM patients.

Mitiglinide administration also decreased free fatty acids (FFA) at 60 minutes after a meal tolerance test in T2DM patients. ${ }^{16}$ Mitiglinide significantly lowered hemoglobin $\mathrm{A}_{1 \mathrm{c}}\left(\mathrm{HbA}_{1 \mathrm{c}}\right)$ levels, increased 1,5-anhydroglucitol (1,5-AG) levels after 6 months, and significantly decreased urinary albumin levels after 12 months. ${ }^{16}$ These data suggest that mitiglinide clearly improves postprandial hyperglycemia, which is crucial to treating metabolic disorders, including insulin resistance and dyslipidemia, in T2DM patients.

Evidence from previous studies suggests the importance of the association between postprandial hyperglycemia and endothelial dysfunction in diabetic patients. The outcomes 
of 12 -week interventions with $300 \mathrm{mg} /$ day acarbose, $270 \mathrm{mg} /$ day nateglinide, or no medication were compared among patients with new-onset T2DM. ${ }^{37}$ Only acarbose improved postprandial endothelial function, as assessed by the percent of flow-mediated dilation at 0 minutes and 120 minutes after a cookie test.

To investigate whether mitiglinide improves endothelial function, a pilot study on mitiglinide add-on therapy with pioglitazone was conducted on T2DM patients whose blood sugar was insufficiently controlled with pioglitazone monotherapy. In eight patients with T2DM, mitiglinide was administered as add-on therapy with $10 \mathrm{mg}$ /day of pioglitazone for 12 weeks. Endothelial function was measured by the reactive hyperemia peripheral arterial tonometry (Itamar Medical, Ltd, Caesarea, Israel) technique in all patients before and after the intervention. ${ }^{38,39}$ Mitiglinide add-on therapy significantly improved the reactive hyperemia peripheral arterial tonometry index in DM patients receiving pioglitazone monotherapy. ${ }^{40}$ Significant $\mathrm{HbA}_{1 \mathrm{c}}$ reductions were also observed with no other modifications of lifestyle or other drug administration; however, there was no reduction in triglyceride levels, low density lipoprotein cholesterol levels, body weight, or waist circumference. In T2DM patients, combination therapy with mitiglinide and pioglitazone resulted in marked improvements in $\mathrm{HbA}_{1 \mathrm{c}}$ levels and endothelial function. In 16 patients with T2DM treated with $30 \mathrm{mg}$ /day of mitiglinide, levels of plasma glucose, FFA, and urinary albumin excretion were significantly decreased. ${ }^{16}$ One of the mechanisms underlying the efficacy of this agent might be the reduction in circulating levels of FFA with mitiglinide administration. Recently, the use of Roux-en-Y gastric bypass as bariatric surgery has been increasing. Treatment with mitiglinide before glucose loading in a patient who received Roux-en-Y gastric bypass resulted in a significant elevation of intact glucagon-like peptide-1 (GLP-1) secretion $\left(9 \%\right.$ increase in area under the curve $\left.[\mathrm{AUC}]_{0-180 \mathrm{~min}}\right)$, while total glucose-dependent insulinotropic polypeptide secretion was further decreased $\left(-48 \%\right.$ decrease in $\left.\mathrm{AUC}_{0-180 \min }\right)$. The increased secretion of intact GLP-1 with mitiglinide administration suggested that this agent exerts a direct effect on GLP-1 secretion from GLP-1-secreting L-cells. ${ }^{41}$

\section{Benefits of combination therapy with voglibose}

It should be noted that $\alpha$-GI might have other beneficial effects on the secretion of incretins, including GLP-1 and glucose-dependent insulinotropic polypeptide, which have been reported to exert trophic effects on $\beta$-cells. In animal models, native GLP-1 stimulates $\beta$-cell proliferation and inhibits apoptosis, possibly increasing $\beta$-cell mass and function. ${ }^{42}$

When two groups (one in which the subjects received preprandial monotherapy with mitiglinide, $20 \mathrm{mg}$ three times a day [tid], and the other in which the subjects received preprandial combined therapy with mitiglinide $10 \mathrm{mg}$ tid and voglibose $0.2 \mathrm{mg}$ tid for 12 weeks) were compared to assess the beneficial effects, as well as other influences, both groups showed an improvement in 1,5-AG with significant and comparable increases in 1,5-AG levels. In addition, the combined therapy group also showed a significant increase in the $\mathrm{AUC}_{0-120}$ of active GLP-1 levels (Table 1), as well as a reduction in postprandial insulin secretion. This change was also supported by the study of Ono et al..$^{43}$ When mitiglinide was given concomitantly with voglibose for 12 weeks, the active GLP-1 levels at 60 minutes and 120 minutes after a meal were significantly increased (Table 1$).{ }^{19}$

Table I Changes in parameters from week 0 to week 12 in the concomitant voglibose group and the double mitiglinide group

\begin{tabular}{|c|c|c|c|c|c|c|}
\hline & \multicolumn{2}{|c|}{ Concomitant voglibose group $(n=10)$} & \multirow{2}{*}{$\begin{array}{l}P \text {-value } \\
\text { (versus } \\
\text { week } 0 \text { ) }\end{array}$} & \multicolumn{2}{|c|}{ Double mitiglinide group $(n=10)$} & \multirow{2}{*}{$\begin{array}{l}\text { P-value } \\
\text { (versus } \\
\text { week 0) }\end{array}$} \\
\hline & Week 0 & Week 12 & & Week 0 & Week 12 & \\
\hline $\mathrm{HbA}_{\mathrm{Ic}}(\%)$ & $8.1 \pm 0.6$ & $7.9 \pm 0.8$ & NS & $7.4 \pm 0.3$ & $7.2 \pm 0.4$ & 0.0469 \\
\hline GA (\%) & $22.3 \pm 2.2$ & $21.8 \pm 3.4$ & NS & $22.1 \pm 2.7$ & $20.5 \pm 1.9$ & 0.0078 \\
\hline I,5 AG $(\mu g / m L)$ & $3.5 \pm 2.9$ & $6.9 \pm 6.6$ & 0.0039 & $4.1 \pm 2.0$ & $5.9 \pm 3.6$ & 0.0234 \\
\hline Fasting plasma glucose (mg/dL) & $179.5 \pm 30.8$ & $168.7 \pm 27.6$ & NS & $156.3 \pm 18.0$ & $150.5 \pm 16.2$ & NS \\
\hline Weight $(\mathrm{kg})$ & $71.9 \pm 12.7$ & $70.8 \pm 12.6$ & 0.0039 & $60.0 \pm 14.0$ & $59.8 \pm 16.8$ & NS \\
\hline Glucose $\mathrm{AUC}_{0-120}(\mathrm{mg}$ hours/dL) & $30196.5 \pm 5627.4$ & $26044.5 \pm 4394.3$ & 0.0098 & $25363.5 \pm 5443.6$ & $24|80.0 \pm 5366|$. & NS \\
\hline Insulin $A \cup C_{0-120}(\mu \cup$ hours $/ \mathrm{mL})$ & $3741.8 \pm 2184.6$ & $3229.8 \pm 1551.8$ & NS & $2878.0 \pm 1840.5$ & $3221.1 \pm 2365.3$ & NS \\
\hline GLP-I AUC & $648.9 \pm 91.6$ & $843.3 \pm 336.9$ & 0.0137 & $604.2 \pm 58.8$ & $664.5 \pm 103.7$ & NS \\
\hline GIP AUC $_{0-120}(\mathrm{pg}$ hours $/ \mathrm{mL})$ & $24|5| . \mid \pm 9506.3$ & $22856.1 \pm 10277.1$ & NS & $24481.2 \pm 8888.7$ & $2675 I .1 \pm 12 \mid 45.2$ & NS \\
\hline Glucagon $\mathrm{AUC}_{0-120}$ (pg hours $\left./ \mathrm{mL}\right)$ & $10347.6 \pm 2029.6$ & $11090.4 \pm 1948.1$ & NS & $10373.0 \pm 2590.2$ & $9820.5 \pm 2151.4$ & NS \\
\hline
\end{tabular}

Notes: Data are represented as the mean \pm standard deviation. For intergroup comparison, Wilcoxon signed rank test was used. ๑ 2010 Asian Association for the Study of Diabetes and Blackwell Publishing Asia Pty Ltd. Adapted with permission from Katsuno et al. ${ }^{19}$

Abbreviations: $n$, number; $\mathrm{HbA}_{1 \mathrm{c}}$, hemoglobin $\mathrm{A}_{\mathrm{Ic}}$; NS, not significant; GA, glycoalbumin; I,5-AG, I,5-anhydroglucitol; AUC, area under the curve; GLP-I, glucagon-like peptide I; GIP, glucose-dependent insulinotropic polypeptide. 
The active GLP-1 level was reported to increase when voglibose was given to ob/ob mice for 3-4 weeks. ${ }^{44}$ It appears that continuous administration of voglibose evoked chronic glucose absorption from the small intestine and increased the amount of undigested carbohydrates, which results in constant stimulation of the lower small intestine and the large intestine, thus promoting differentiation and proliferation of GLP-secreting cells. ${ }^{45}$

These findings suggest that concomitant use of mitiglinide and voglibose could minimize excessive insulin secretion, and that the GLP-1 increase might diminish insulin secretory overload. This combination appears to be suitable for Japanese people, who consume more carbohydrates such as polished rice, than Caucasians.

Because impairment of early insulin secretion is closely related to the pathogenesis of T2DM in Japanese patients and the secretory capacity of pancreatic $\beta$-cells is lower in Japanese than in Caucasian patients in the USA and Europe ${ }^{46-48}$ concomitant use of mitiglinide with voglibose might be more useful even in fairly well-controlled obese Japanese patients with T2DM, so long as the switch to concomitant treatment is made at an early stage.

\section{Mitiglinide and voglibose: clinical trial data for combination therapy}

The effects of a fixed-dose combination of $10 \mathrm{mg}$ of mitiglinide and $0.2 \mathrm{mg}$ of voglibose on postprandial glycemic excursions in Japanese T2DM patients were reported. After a 2-week baseline period, eleven T2DM patients were treated with mitiglinide alone for 2 weeks and with the mitiglinide/voglibose combination for 6 weeks. Postprandial glycemic excursions after all three meals, as assessed by self-monitoring of blood glucose, were significantly lower during the combination than during the baseline period, as well as after lunch and dinner during the combination as compared to the mitiglinide period. The meal tolerance test confirmed that the magnitude of postprandial hyperglycemia was significantly lower, with significantly greater early-phase serum insulin secretion and sustained GLP-1 production, during the combination as compared with the baseline period. Overall glycemic control parameters also improved significantly during the combination as compared with the baseline period. This study demonstrated that the mitiglinide/voglibose combination therapy can reduce postprandial insulin secretion and blunt diurnal glycemic changes more markedly than monotherapy with mitiglinide. ${ }^{43}$

The effects of mitiglinide and voglibose, alone and in combination, on metabolic responses after a test meal in
Japanese patients with T2DM were reported. This randomized cross-over study consisted of four periods. During the first period, all patients $(n=12)$ received water only (control period). During the next three periods, the patients received $10 \mathrm{mg}$ of mitiglinide, $0.2 \mathrm{mg}$ of voglibose, or the two combined, in random order. The combination reduced postprandial glucose levels as compared with either mitiglinide or voglibose alone, particularly at 30-90 minutes, which significantly exceeded the effects of mitiglinide only $(P<0.05)$. Mitiglinide and the combination therapy both restored the early insulin response, but the combination provided an insulin-sparing effect as compared with mitiglinide alone. The combination improved postprandial lipid profiles, combining the effects of both drugs. ${ }^{20}$

The efficacy of the combination of mitiglinide and voglibose for diabetic patients on hemodialysis (HD) was reported. An open-label randomized study was performed with 36 T2DM patients with poor glycemic control on HD and receiving daily doses of voglibose $(0.9 \mathrm{mg})$. The efficacy of this treatment was determined by monitoring plasma glucose, $\mathrm{HbA}_{1 \mathrm{c}}$, and glycated albumin (GA) levels using a homeostasis model assessment of insulin resistance. The final dose of mitiglinide was $22.9 \pm 8.9 \mathrm{mg}$ (mean \pm standard deviation) $(0.41 \mathrm{mg} / \mathrm{kg})$ daily. Mitiglinide reduced fasting plasma glucose and GA levels after 4 weeks and $\mathrm{HbA}_{1 \mathrm{c}}$ levels after 8 weeks. Triglyceride levels and homeostasis model assessment of insulin resistance values also decreased significantly after mitiglinide treatment. Safety and tolerance were determined by monitoring clinical and laboratory parameters. No significant changes in blood pressure levels or serious adverse effects such as hypoglycemia or liver impairment were observed. This study suggested that combination therapy with mitiglinide and voglibose has potential as a treatment for diabetic patients on HD. ${ }^{18}$

The efficacy of two options in T2DM patients whose blood glucose had not been well controlled with mitiglinide (30 mg/day) alone was evaluated. In total, 20 patients were included in the add-on therapy group and then divided into two subgroups: concomitant voglibose, in which mitiglinide was given concomitantly with voglibose $(0.6 \mathrm{mg} /$ day $)$; and double mitiglinide, in which a double dose of mitiglinide (60 mg/day) was given. Table 1 shows the results obtained after the meal tolerance tests $(460 \mathrm{kcal} ; 56.5 \mathrm{~g}$ of carbohydrates, $18 \mathrm{~g}$ of protein, and $18 \mathrm{~g}$ of fat) performed at week 0 (at the initiation of add-on therapy) and at week 12. At week $12, \mathrm{HbA}_{1 \mathrm{c}}$, GA, 1,5-AG, fasting plasma glucose, weight, glucose, insulin, active GLP-1, total GIP, and glucagon levels were measured. The plasma level of 1,5-AG was improved 
at week 12 in both groups. Intragroup comparison of the concomitant voglibose group revealed a significant reduction in the effect on insulin secretion and a significant increase in GLP-1 activity. In the concomitant voglibose group, the plasma insulin level decreased significantly and the plasma active GLP-1 level increased significantly during the meal tolerance test at week 12; thus, body weight decreased significantly only in the concomitant voglibose group. These findings suggested that concomitant administration of mitiglinide with voglibose achieves better glycemic control, particularly in the postprandial period, without weight gain and might have beneficial effects in T2DM patients at risk for macrovascular complications (Table 1). ${ }^{19}$

\section{Safety and tolerability}

The therapeutic options for patients with T2DM and chronic kidney disease (CKD) are limited because the decreased glomerular filtration rate results in an accumulation of certain drugs and/or their metabolites (Table 2). ${ }^{49}$ Mitiglinide can also be safely used in CKD patients. ${ }^{50}$ However, careful observation should be recommended, especially in HD patients, in whom therapy should be initiated at a low dose with careful attention to hypoglycemia. The same may be true in the case of combined therapy with mitiglinide and voglibose. ${ }^{18}$ In non-HD CKD patients, repeatedly inquiring about hypoglycemic symptoms and adverse events might be the most important and useful means of monitoring these patients for the presence of hypoglycemia. ${ }^{51}$

As described above, combination therapy with mitiglinide and voglibose improved glycemic control in T2DM patients even on HD. There were no significant changes in the levels of the systolic or diastolic blood pressure during the study period. No statistically significant changes were observed in any other parameters with combined data such as the cardiothoracic ratio and dry weight. There were no significant differences in hemoglobin or erythropoietin levels at any time during the treatment period. During the study period, none of the patients exhibited significant increases in adverse effects such as hypoglycemia, liver impairment, skin rash, fluid overload, or edema. ${ }^{18}$ This study suggested that combination therapy with mitiglinide and voglibose might have adequate safety and tolerability for the treatment of diabetic patients, even those on HD.

Moreover, in the other study, when mitiglinide (30 mg/day) was given concomitantly with voglibose (0.6 mg/day), body weight decreased significantly, whereas

Table 2 Dosing adjustment by CKD stage for meglitinides, $\alpha$-glucosidase inhibitors, and DPP-4 inhibitors

\begin{tabular}{|c|c|c|c|}
\hline Class & Drug & $\begin{array}{l}\text { Dosing recommendation } \\
\text { CKD stage } 3 \text {, stage } 4 \text {, or kidney transplant }\end{array}$ & Dosing recommendation, dialysis \\
\hline \multirow[t]{2}{*}{ Meglitinides } & Repaglinide & $\begin{array}{l}\text { No dose adjustment necessary } \\
\text { Initiate at } 0.5 \mathrm{mg} \text { dose when GFR }<40 \mathrm{~mL} / \text { minute } / \mathrm{I} .73 \mathrm{~m}^{2}\end{array}$ & $\begin{array}{l}\text { No dose adjustment necessary } \\
\text { Initiate at low dose } \\
\text { Not available in Japan }\end{array}$ \\
\hline & $\begin{array}{l}\text { Nateglinide } \\
\text { Mitiglinide }\end{array}$ & $\begin{array}{l}\text { Initiate at low dose, } 60 \mathrm{mg} \text { meglitinides before each meal } \\
\text { No dose adjustment necessary } \\
\text { Not available in the US }\end{array}$ & $\begin{array}{l}\text { Avoid } \\
\text { Initiate at low dose of } 5 \mathrm{mg} \text { before } \\
\text { each meal } \\
\text { Not available in the US }\end{array}$ \\
\hline $\begin{array}{l}\alpha \text {-glucosidase } \\
\text { inhibitors }\end{array}$ & Acarbose & $\begin{array}{l}\text { Not recommended in patients with } \mathrm{sCr}>2 \mathrm{mg} / \mathrm{dL} \text { in the US } \\
\text { No dose adjustment necessary in Japan }\end{array}$ & $\begin{array}{l}\text { Not recommended in the US } \\
\text { Caution recommended in Japan }\end{array}$ \\
\hline \multirow{2}{*}{ inhibitors } & Miglitol & $\begin{array}{l}\text { Not recommended in patients with } \mathrm{sCr}>2 \mathrm{mg} / \mathrm{dL} \text { in the US } \\
\text { Caution recommended in Japan }\end{array}$ & $\begin{array}{l}\text { Not recommended in the US } \\
\text { Caution recommended in Japan }\end{array}$ \\
\hline & Voglibose & $\begin{array}{l}\text { Not available in the US } \\
\text { No dose adjustment necessary in Japan }\end{array}$ & $\begin{array}{l}\text { Not recommended in the US } \\
\text { No dose adjustment necessary in Japan }\end{array}$ \\
\hline \multirow[t]{3}{*}{ inhibitors } & Sitagliptin & $\begin{array}{l}\text { Reduce dose by } 50 \%(50 \mathrm{mg} / \text { day }) \text { when GFR }<50 \mathrm{~mL} / \text { minute/ } \\
1.73 \mathrm{~m}^{2} \text { and } \geq 30 \mathrm{~mL} / \text { minute/ } / .73 \mathrm{~m}^{2} \text {, and by } 75 \% \\
(25 \mathrm{mg} / \text { day }) \text { when } \mathrm{GFR}<30 \mathrm{~mL} / \text { minute } / 1.73 \mathrm{~m}^{2}\end{array}$ & Reduce dose by $75 \%$ (25 mg/day) \\
\hline & Vildagliptin & $\begin{array}{l}\text { Initiate at low dose } \\
\text { Not available in the US }\end{array}$ & $\begin{array}{l}\text { Initiate at low dose } \\
\text { Not available in the US }\end{array}$ \\
\hline & Alogliptin & $\begin{array}{l}\text { Reduce dose by } 50 \%(12.5 \mathrm{mg} / \text { day }) \\
\text { when } \mathrm{GFR}<50 \mathrm{~mL} / \text { minute } / \mathrm{I} .73 \mathrm{~m}^{2} \text { and } \geq 30 \mathrm{~mL} / \text { minute } / \mathrm{I} .73 \mathrm{~m}^{2} \text {, } \\
\text { and by } 75 \%(6.25 \mathrm{mg} / \text { day }) \text { when } \mathrm{GFR}<30 \mathrm{~mL} / \text { minute } / 1.73 \mathrm{~m}^{2} \\
\text { Not available in the US }\end{array}$ & $\begin{array}{l}\text { Reduce dose by } 75 \%(6.25 \mathrm{mg} / \text { day }) \\
\text { Not available in the US }\end{array}$ \\
\hline
\end{tabular}

Note: Data from Abe et al. ${ }^{49}$

Abbreviations: CKD, chronic kidney disease; DPP-4, dipeptidyl peptidase-4; GFR, glomerular filtration rate; sCR, serum creatinine. 
there was no significant change when a double dose of mitiglinide was given (60 mg/day). No symptoms of hypoglycemia were noted in either group at any time during the study period. ${ }^{19}$

\section{Clinical application of mitiglinide and voglibose}

The potent and selective dipeptidyl peptidase- 4 inhibitor (DPP-4), vildagliptin, improves glycemic control in T2DM patients through incretin hormone-mediated increases in both $\alpha$-cell and $\beta$-cell responsiveness to glucose. Vildagliptin has been evaluated in several subjects with T2DM, including patients on HD three times a week for about 3 years due to diabetic nephropathy. The efficacy and safety of vildagliptin (30 patients) versus controls (21 patients) with $\mathrm{T} 2 \mathrm{DM}$ and a mean starting $\mathrm{HbA}_{1 \mathrm{c}}$ of $6.0 \%$ were demonstrated in a prospective open label study. Criteria for adding vildagliptin included $\mathrm{HbA}_{1 \mathrm{c}}$ after either dietary intervention alone, or therapy with mitiglinide or voglibose for 8 weeks, an $\mathrm{HbA}_{1 \mathrm{c}}$ level greater than $7 \%$, and a GA level greater than $21 \%$, as levels of $\mathrm{HbA}_{1 \mathrm{c}}$ may be underestimated in patients with renal failure on dialysis. Vildagliptin was added to the prior antidiabetic therapy after the 8-week observation period. The treatment was initiated at a dose of $50 \mathrm{mg}$ /day for the first 8 weeks, with an option for up-titration if $\mathrm{HbA}_{1 \mathrm{c}}$ targets were not achieved, with a mean final vildagliptin dose of $80 \mathrm{mg} /$ day. Vildagliptin treatment reduced $\mathrm{HbA}_{1 \mathrm{c}}$ from $6.7 \%$ to $6.1 \%$ over 24 weeks. No serious adverse effects such as hypoglycemia or liver impairment were observed in any of the patients. All 30 patients in the vildagliptin group received antidiabetic therapy; 21 patients in the control group received no antidiabetic medications. When subjects were divided into the vildagliptin monotherapy group $(\mathrm{n}=9)$ and the combination therapy group (vildagliptin plus mitiglinide and/or voglibose; $n=21$ ), there were no significant differences in age, sex distribution, body mass index, reductions in $\mathrm{HbA}_{1 \mathrm{c}}$ and postprandial glucose levels, or in the vildagliptin dose, but the GA reduction was greater in the monotherapy group. This study suggests that vildagliptin combined with mitiglinide or voglibose has potential, due to its safety and tolerability, for the treatment of diabetics with CKD. ${ }^{52}$

The long-term efficacy and safety of DPP-4 inhibitors remain largely unknown. However, combination therapy with a DPP-4 inhibitor and mitiglinide and/or voglibose is associated with a lower risk of hypoglycemia than SU agents. DPP-4 inhibitors, such as vildagliptin, when combined with mitiglinide and/or voglibose, appear to be both safe and tolerable treatments for diabetes.

\section{Conclusion}

In conclusion, we reviewed the effects of combination therapy with mitiglinide and voglibose on postprandial hyperglycemia and vascular endothelial function in T2DM patients. The improvement of postprandial hyperglycemia may be crucial to preventing atherosclerosis progression and cardiovascular events. The combined use of mitiglinide and voglibose reduces postprandial insulin secretion and is expected to reduce diurnal glycemic changes while enhancing GLP-1 activity. Therefore, such therapy is considered to be suitable for achieving strict postprandial glycemic control and can also be administered to diabetic patients with CKD. However, the studies presented herein were all conducted in a small number of subjects. Further studies involving a larger number of subjects are required, anticipating future progress in this field.

\section{Disclosure}

The authors report no conflicts of interest in this work.

\section{References}

1. Garcia MJ, McNamara PM, Gordon T, Kannel WB. Morbidity and mortality in diabetics in the Framingham population. Sixteen year follow-up study. Diabetes. 1974;23(2):105-111.

2. Zilversmit DB. Atherogenesis: a postprandial phenomenon. Circulation. 1979;60(3):473-485.

3. Ebenbichler CF, Kirchmair R, Egger C, Patsch JR. Postprandial state and atherosclerosis. Curr Opin Lipidol. 1995;6(5):286-290.

4. Lefèbvre PJ, Scheen AJ. The postprandial state and risk of cardiovascular disease. Diabet Med. 1998;15 Suppl 4:S63-S68.

5. Ceriello A. The post-prandial state and cardiovascular disease: relevance to diabetes mellitus. Diabetes Metab Res Rev. 2000;16(2):125-132.

6. Bonora E, Muggeo M. Postprandial blood glucose as a risk factor for cardiovascular disease in type II diabetes: the epidemiological evidence. Diabetologia. 2001;44(12):2107-2114.

7. Balkau B, Shipley M, Jarrett RJ, et al. High blood glucose concentration is a risk factor for mortality in middle-aged nondiabetic men. 20-year follow-up in the Whitehall Study, the Paris Prospective Study, and the Helsinki Policemen Study. Diabetes Care. 1998;21(3):360-367.

8. Glucose tolerance and mortality: comparison of WHO and American Diabetes Association diagnostic criteria. The DECODE study group. European Diabetes Epidemiology Group. Diabetes Epidemiology: Collaborative analysis of Diagnostic criteria in Europe. Lancet. 1999; 354(9179):617-621.

9. Chiasson JL, Josse RG, Gomis R, Hanefeld M, Karasik A, Laakso M; STOP-NIDDM Trial Research Group. Acarbose treatment and the risk of cardiovascular disease and hypertension in patients with impaired glucose tolerance: the STOP-NIDDM trial. JAMA. 2003;290(4):486-494.

10. Cheng AY, Fantus IG. Oral antihyperglycemic therapy for type 2 diabetes mellitus. CMAJ. 2005;172(2):213-226.

11. Harada S, Nomura M, Nakaya Y, Ito S. Nateglinide with glibenclamide examination using the respiratory quotient (RQ). J Med Invest. 2006;53(3-4):303-309. 
12. Vichayanrat A, Ploybutr S, Tunlakit M, Watanakejorn P. Efficacy and safety of voglibose in comparison with acarbose in type 2 diabetic patients. Diabetes Res Clin Pract. 2002;55(2):99-103.

13. Kawamori R, Tajima N, Iwamoto Y, Kashiwagi A, Shimamoto K, Kaku K; Voglibose Ph-3 Study Group. Voglibose for prevention of type 2 diabetes mellitus: a randomised, double-blind trial in Japanese individuals with impaired glucose tolerance. Lancet. 2009;373(9675): $1607-1614$

14. Malaisse WJ. Mitiglinide: a rapid- and short-acting non-sulfonylurea insulinotropic agent for the treatment of type 2 diabetic patients. Expert Opin Pharmacother. 2008;9(15):2691-2698.

15. Gao X; Mitiglinide Versus Nateglinide Comparison Study Group. Multicentre, double-blind, randomized study of mitiglinide compared with nateglinide in type 2 diabetes mellitus patients in China. J Int Med Res. 2009;37(3):812-821.

16. Konya H, Miuchi M, Konishi K, et al. Pleiotropic effects of mitiglinide in type 2 diabetes mellitus. J Int Med Res. 2009;37(6):1904-1912.

17. Phillippe HM, Wargo KA. Mitiglinide: a novel agent for the treatment of type 2 diabetes mellitus. Ann Pharmacother. 2010;44(10): $1615-1623$.

18. Abe M, Okada K, Maruyama T, Maruyama N, Matsumoto K. Combination therapy with mitiglinide and voglibose improves glycemic control in type 2 diabetic patients on hemodialysis. Expert Opin Pharmacother. 2010;11(2):169-176.

19. Katsuno T, Wantanabe N, Nagai E, et al. Comparison of efficacy of concomitant administration of mitiglinide with voglibose and double dose of mitiglinide in patients with type 2 diabetes mellitus. $J$ Diabetes Investig. 2011;2(3):204-209.

20. Inoue M. Tighter control of postprandial hyperglycemia with mitiglinide/voglibose fixed-dose combination in Japanese patients with type 2 diabetes mellitus. Expert Opin Pharmacother. 2012;13(16): 2257-2268

21. Pharmaceutical and Medical Devices Agency. Deliberation Report. March 23, 2011 (Voglibose/Mitiglinide Tablets). 2011.

22. Mogami H, Shibata H, Nobusawa R, et al. Inhibition of ATP-sensitive $\mathrm{K}+$ channel by a non-sulfonylurea compound KAD-1229 in a pancreatic beta-cell line, MIN 6 cell. Eur J Pharmacol. 1994;269(3): 293-298.

23. Reimann F, Proks P, Ashcroft FM. Effects of mitiglinide (S 21403) on Kir6.2/SUR1, Kir6.2/SUR2A and Kir6.2/SUR2B types of ATP-sensitive potassium channel. Br J Pharmacol. 2001;132(7): $1542-1548$.

24. Mori Y, Ojima K, Fuujimori Y, et al. Effects of mitiglinide on glucoseinduced insulin release into the portal vein and fat-induced triglyceride elevation in prediabetic and diabetic OLETF rats. Endocrine. 2006;29(2):309-315.

25. Toyoda Y, Mizutani K, Miwa I. Increase in hepatic glucose metabolism by mitiglinide calcium dehydrate-induced translocation of glucokinase from the nuclear to the cytoplasm. Prog Med. 2008;28:1951-1958. Japanese.

26. GLUFAST ${ }^{\circledR}$ tablets [package insert] (10th edition). Tokyo, Japan: Kissei Pharmaceutical Co, Ltd; 2012.

27. FASTIC ${ }^{\circledR}$ tablets [package insert] (24th edition). Tokyo, Japan: Mochida Pharmaceutical Co, Ltd; 2012.

28. SUREPOST ${ }^{\circledR}$ tablets [package insert] (4th edition). Osaka, Japan: Dainippon Sumitomo Pharma Co, Ltd; 2013.

29. Sunaga Y, Gonoi T, Shibasaki T, et al. The effects of mitiglinide (KAD-1229), a new anti-diabetic drug, on ATP-sensitive K+ channels and insulin secretion: comparison with the sulfonylureas and nateglinide. Eur J Pharmacol. 2001;431(1):119-125.

30. Ohnota H, Koizumi T, Tsutsumi N, Kobayashi M, Inoue S, Sato F. Novel rapid- and short-acting hypoglycemic agent, a calcium(2 s)-2-benzyl-3(cis-hexahydro-2-isoindolinylcarbonyl) propionate (KAD-1229) that acts on the sulfonylurea receptor: comparison of effects between KAD-1229 and gliclazide. J Pharmacol Exp Ther. 1994;269(2):489-495.
31. Assaloni R, Da Ros R, Quagliaro L, et al. Effects of S21403 (mitiglinide) on postprandial generation of oxidative stress and inflammation in type 2 diabetic patients. Diabetologia. 2005;48(9):1919-1924.

32. Thisted H, Johnsen SP, Rungby J. Sulfonylureas and the risk of myocardial infarction. Metabolism. 2006;55(5 Suppl 1):S16-S19.

33. Quast U, Stephan D, Bieger S, Russ U. The impact of ATP-sensitive $\mathrm{K}+$ channel subtype selectivity of insulin secretagogues for the coronary vasculature and the myocardium. Diabetes. 2004;53 Suppl 3: S156-S164.

34. Abdelmoneim AS, Hasenbank SE, Seubert JM, Brocks DR, Light PE, Simpson SH. Variations in tissue selectivity amongst insulin secretagogues: a systematic review. Diabetes Obes Metab. 2012;14(2): 130-138.

35. Ogawa K, Ikewaki K, Taniguchi I, et al. Mitiglinide, a novel oral hypoglycemic agent, preserves the cardioprotective effect of ischemic preconditioning in isolated perfused rat hearts. Int Heart J. 2007;48(3): 337-345.

36. Maruyama I, Tomiyama Y, Maruyama K, et al. Effects of mitiglinide and sulfonylureas in isolated canine coronary arteries and perfused rat hearts. Eur J Pharmacol. 2006;531(1-3):194-200.

37. Kato $T$, Inoue $T$, Node K. Postprandial endothelial dysfunction in subjects with new-onset type 2 diabetes: an acarbose and nateglinide comparative study. Cardiovasc Diabetol. 2010;9:12.

38. Yamaoka-Tojo M, Tojo T, Izumi T. Beyond cholesterol lowering: pleiotropic effects of bile acid binding resins against cardiovascular disease risk factors in patients with metabolic syndrome. Curr Vasc Pharmacol. 2008;6(4):271-281.

39. Yamaoka-Tojo M, Tojo T, Kosugi R, et al. Effects of ezetimibe add-on therapy for high-risk patients with dyslipidemia. Lipids Health Dis. 2009;8:41.

40. Kitasato L, Tojo T, Hatakeyama Y, Kameda R, Hashikata T, Yamaoka-Tojo M. Postprandial hyperglycemia and endothelial function in type 2 diabetes: focus on mitiglinide. Cardiovasc Diabetol. 2012; 11:79.

41. Kamitani M, Konya H, Miuchi M, et al. Effects of mitiglinide on incretin hormone responses in a case of impaired glucose tolerance following total gastrectomy with Roux en Y rebuilding. $J$ Diabetes Invest. 2012;3(Suppl 1):S237.

42. Kim W, Egan JM. The role of incretins in glucose homeostasis and diabetes treatment. Pharmacol Rev. 2008;60(4):470-512.

43. Ono Y, Kameda H, Cho KY. Mitiglinide/voglibose fixed-dose combination improves postprandial glycemic excursions in Japanese patients with type 2 diabetes mellitus. Expert Opin Pharmacother. 2013;14(4):361-370.

44. Moritoh Y, Takeuchi K, Hazama M. Chronic administration of voglibose, an alpha-glucosidase inhibitor, increases active glucagon-like peptide-1 levels by increasing its secretion and decreasing dipeptidyl peptidase-4 activity in ob/ob mice. J Pharmacol Exp Ther. 2009;329(2):669-676.

45. Cani PD, Hoste S, Guiot Y, Delzenne NM. Dietary non-digestible carbohydrates promote L-cell differentiation in the proximal colon of rats. Br J Nutr. 2007;98(1):32-37.

46. Kosaka K, Hagura R, Kuzuya T. Insulin responses in equivocal and definite diabetes, with special reference to subjects who had mild glucose intolerance but later developed definite diabetes. Diabetes. 1977;26(10):944-952.

47. Mitsui R, Fukushima M, Nishi Y, et al. Factors responsible for deteriorating glucose tolerance in newly diagnosed type 2 diabetes in Japanese men. Metab Clin Exp. 2006;55(1):53-58.

48. Kadowaki T, Miyake Y, Hagura R, et al. Risk factors for worsening to diabetes in subjects with impaired glucose tolerance. Diabetologia. 1984;26(1):44-49.

49. Abe M, Okada K, Soma M. Antidiabetic agents in patients with chronic kidney disease and end-stage renal disease on dialysis: metabolism and clinical practice. Curr Drug Metab. 2011;12(1):57-69. 
50. Abe M, Okada K, Maruyama T, Maruyama N, Matsumoto K. Efficacy and safety of mitiglinide in diabetic patients on maintenance hemodialysis. Endocr J. 2010;57(7):579-586.

51. Tschöpe D, Bramlage P, Binz C, et al. Antidiabetic pharmacotherapy and anamnestic hypoglycemia in a large cohort of type 2 diabetic patients - an analysis of the DiaRegis registry. Cardiovasc Diabetol. 2011;10:66.
52. Ito M, Abe M, Okada K, et al. The dipeptidyl peptidase-4 (DPP-4) inhibitor vildagliptin improves glycemic control in type 2 diabetic patients undergoing hemodialysis. Endocr J. 2011;58(11):979-987.

Diabetes, Metabolic Syndrome and Obesity: Targets and Therapy

\section{Publish your work in this journal}

Diabetes, Metabolic Syndrome and Obesity: Targets and Therapy is an international, peer-reviewed open-access journal committed to the rapid publication of the latest laboratory and clinical findings in the fields of diabetes, metabolic syndrome and obesity research. Original research, review, case reports, hypothesis formation, expert opinion and commentaries are all considered for publication. The manuscript management system is completely online and includes a very quick and fair peer-review system, which is all easy to use. Visit http://www.dovepress.com/testimonials.php to read real quotes from published authors.

Submit your manuscript here: http://www.dovepress.com/diabetes-metabolic-syndrome-and-obesity-targets-and-therapy-journal 